\title{
Water availability, water quality water governance: the future ahead
}

\author{
JOSE GALIZIA TUNDISI ${ }^{1}$, TAKAKO MATSUMURA-TUNDISI ${ }^{2}$, \\ VIRGINIA S. CIMINELLI ${ }^{3}$ \& FRANCISCO A. BARBOSA ${ }^{4}$
}

1 International Institute of Ecology, University of Feevale, INCT-ACQUA, Rua Bento Carlos 750, 13560-660 Centro, São Carlos, São Paulo, Brazil

tundisi@,iie.com.br

2 International Institute of Ecology, INCT-ACQUA, Rua Bento Carlos 750, 13560-660 Centro, São Carlos, São Paulo, Brazil

3 UFMG, INCT-ACQUA, Av. Antonio Carlos 6627, Belo Horizonte, 31270901 MG, Brazil

4 UFMG, INCT-ACQUA, Universidade Federal de Minas Gerais, CP 486 Pampulha, Belo Horizonte, 31270901 MG, Brazil

\begin{abstract}
The major challenge for achieving a sustainable future for water resources and water security is the integration of water availability, water quality and water governance. Water is unevenly distributed on Planet Earth and these disparities are cause of several economic, ecological and social differences in the societies of many countries and regions. As a consequence of human misuse, growth of urbanization and soil degradation, water quality is deteriorating continuously. Key components for the maintenance of water quantity and water quality are the vegetation cover of watersheds, reduction of the demand and new water governance that includes integrated management, predictive evaluation of impacts, and ecosystem services. Future research needs are discussed.
\end{abstract}

\section{INTRODUCTION}

Water availability, water quality and water governance are, today, at the centre of the discussion on Water Security. Four interrelated issues are dominating in water security: water availability, human vulnerability to hazards and disasters, human needs (especially food security) and sustainability (Cook and Bakker 2012). Before the presence of Homo sapiens on Planet Earth, water was available for the ecosystems to maintain biogeochemical cycles and biodiversity. When mankind expanded, occupying the whole globe and diversifying its activities, so the multiple uses and water demands increased and also diversified. Today, $70 \%$ of the water available is used for food production. Hydroelectricity, navigation, public supply and recreation, are all human activities that use most of the remaining freshwater resources of Planet Earth.

As the human demands for water expanded and diversified, so did the contamination and degradation of the water resources and the inland water ecosystems: lakes, rivers, creeks and reservoirs. Agricultural fertilizers, untreated human sewage, industrial effluents, pesticides and herbicides are polluting the freshwater ecosystems at an alarming rate.

In this paper the presentation of results and the discussion will attempt to show how the integration of water availability, water quality and water governance can be fundamental for the water security of human populations and ecosystem functioning.

\section{WATER AVAILABILITY}

Water is a renewable resource. The hydrological cycle has maintained, and will maintain for millennia, the cycle of life on the planet, the biogeochemical cycles of nutrients that are the source of life such as phosphorus, nitrogen, amino acids, proteins and sugars.

The availability of water resources, surface and groundwater in different continents, shows areas of abundance and scarcity, and significant variations within continental scales. Information on supply/demand of water for continents, regions and watersheds still needs to be improved. A strong and well-designed database for each individual watershed with a high degree of reliability is fundamental for advanced water governance. Since water also supports the functioning of ecosystems, this indirect support should be taken into account in the data for the availability of water. The role of water in the biogeochemical cycles, water as a source/sink for gases and ions, 
and its dilution capacity have to be considered in the statistics for water availability. It is necessary to balance ecosystems and human needs of water in a true effort to evaluate the amount of water necessary for each region, continent or watershed. Also, continental or regional changes of hydrological cycles as a consequence of climatic changes (excess rainfall or longer dry periods) have to be included in the future accounting of the water balance for each region, continent or watershed. Water shortage, water scarcity and water stress have to be considered as the context of water availability and water demands (Rogers 2006). Shiklomanov (1999) predicts an increase of $26 \%$ in water uses for agriculture, $61 \%$ in water uses for urban areas, $13 \%$ in water uses for industry and an overall increase in $29 \%$ of world water demand from to 2000 to 2050 . According to Shikolomanov there will be a $49 \%$ of increase in the human population during the same period.

Water security for human population uses has to be considered with the same value as water security to maintain the ecosystems and the functioning of the ecosystems. Table 1 shows the water balance by continent.

Table 1 Water balance by continent ( $\mathrm{km}^{3} /$ year; source Shikolomanov 1993).

\begin{tabular}{lccc}
\hline Continent & Precipitation & Evaporation & Drainage* \\
\hline Europe & 8290 & 5320 & 2970 \\
Asia & 32200 & 18100 & 14100 \\
Africa & 22300 & 17700 & 4600 \\
North America & 18300 & 10100 & 8180 \\
South America & 28400 & 16200 & 12200 \\
Australia/Oceania & 7080 & 4570 & 2510 \\
Antarctic & 2310 & 0 & 2310 \\
Total & 118880 & 71990 & 46870 \\
\hline
\end{tabular}

*Includes drainage into the groundwater basins and continental ice flows in Antarctica.

\section{WATER QUALITY}

Water quality is important and relevant for water security. The history of degradation of water quality shows a continuous deterioration, with increasing complexity mainly in the 20th century and with cumulative impacts on human health. Pollution can impair water availability in many regions, increasing the vulnerability of human populations; the economic impact of degradation of water quality can be accounted as the increase in the costs of treatment, or the impact on human health or loss of biodiversity. The human-caused threats to water quality, such as eutrophication, acidification, sedimentation of surface water, degradation of underground sources and the POPS (persistent organic pollutants), have cumulative effects, increase the costs of water treatment for producing potable water and can lead to several problems of human health and economic losses. Determination of water quality shows increasing complexity as the organic and inorganic components are introduced by air, soil and effluents inputs (Fig. 1).

One key component for the protection of water quality is the mosaic of vegetation, riparian forests and wetlands in watersheds. Protected water sources can produce water of good quality almost free of contaminants with the cost of treatment for potability between US\$2 and US\$5 per $1000 \mathrm{~m}^{3}$. Degraded water sources that are unprotected by vegetation produce water of bad quality (high concentration of suspended material, contaminants). The cost of treatment for potability of these waters can be as high as US $\$ 100$ per $1000 \mathrm{~m}^{3}$ (Tundisi and MatsumuraTundisi 2010, 2012).

The economic connections of water quality deterioration, human health degradation and loss of ecosystem services have to be quantified. Figure 3 shows the overall causes of water quality deterioration. Climatic changes can affect water quality as well as water quantity, resulting in scarcity. The synergistic effect of soil uses, non-point sources of contamination and climatic changes are not known and there is still insufficient scientific information (Cisneros and Tundisi 2012). 


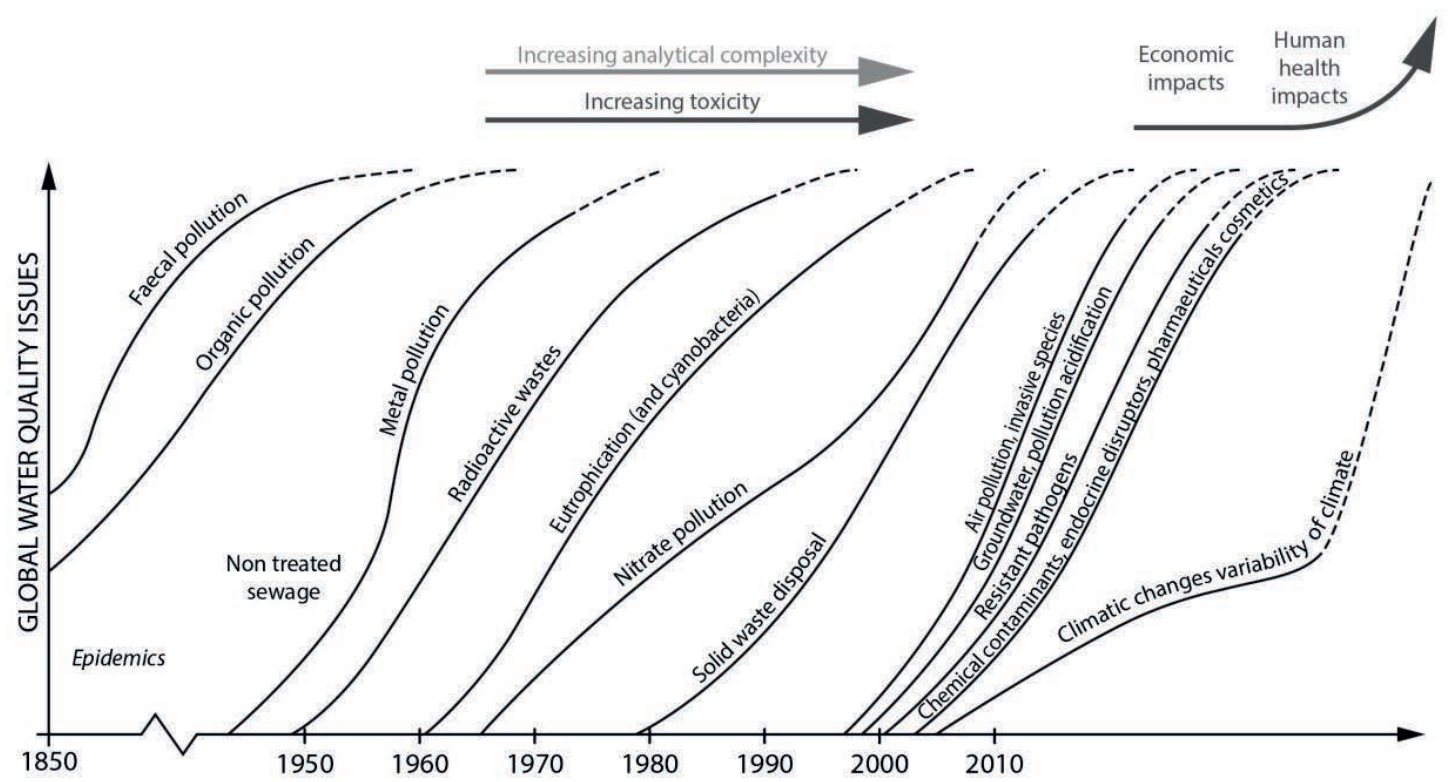

Fig. 1 Trends in water quality in the evolution of water quality problems in industrialized countries. In emerging economies the sequence is more complex. Modified from Chapman (1992).

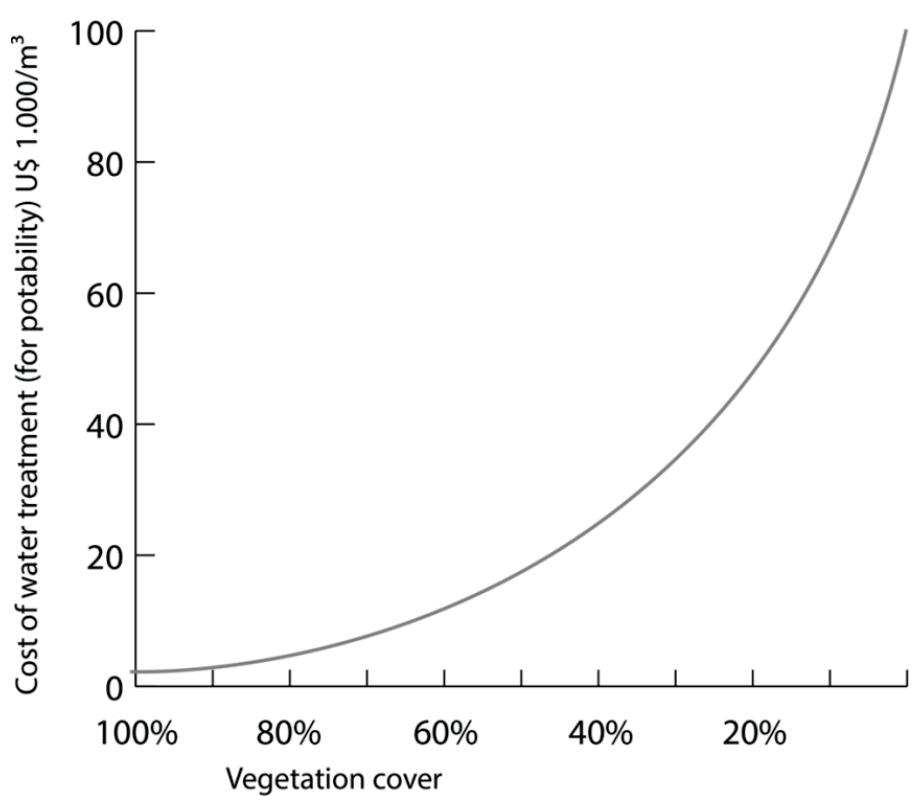

Fig. 2 The cost of water treatment is dependent of the water quality at the source. This is related to soil uses and vegetation cover. Original: J.G. Tundisi.

\section{WATER GOVERNANCE}

An integrated watershed management is a key initiative to overcome the problems caused by water availability, water demand and water quality. The economy of the watersheds and their sustainable development will depend on a basin society (a basin committee and a water agency) that will control the supply/demand, and provide opportunities for the collective participation on governance with the water as the focus, and in implementing planning and actions.

The sustainable development of a watershed (a biogeophysiographical boundary) will depend on this integration of water availability, water uses and water users, control of pollution, soil uses and regulation of agricultural, industrial and sewage discharge (Rogers 2006). To develop a policy for management, a scientific database is fundamental, as well as a cadre of trained scientists and 


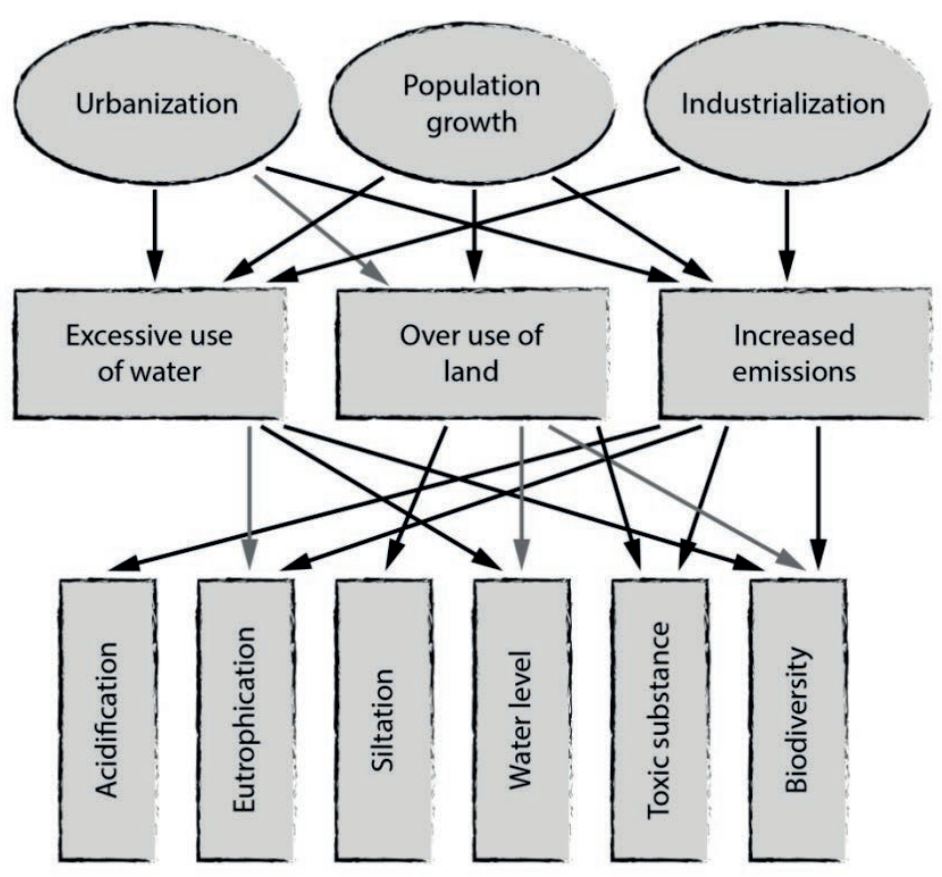

Fig. 3 Main causes of degradation of water quality. Based on a survey of 600 lakes and reservoirs in all continents. Source: ILEC (2011).

managers with a systemic and interdisciplinary background. The governance of water can be improved by introducing modelling and predictive approaches using biogeophysical, economic and social data at a watershed level. Ecohydrological technologies to improve management will be fundamental for advances (Zalewski 2014). It is fundamental also to reduce current water demand rather than to increase water supply for one service (agriculture for example) at the expense of another service (e.g. environmental; Curmi et al. 2013).

\section{RESEARCH NEEDS}

In order to follow up water quality problems it is necessary to keep track of all material flows (in the air, water and soils) and their cycles in organic and inorganic compartments. The interaction of water quality and human health should be followed by permanent research activities, epidemiological statistics and experimental research. Equally important is to understand the relationship between the persistent organic pollutants and their impact on human health and on biodiversity (Jorgensen et al. 2012). Research on resistant pathogens is another fundamental topic for future developments. Also, focus on the impact of land/soil use on water quality is another need for research at the watershed level. Finally, the implementation of networks of competence around the world - integrating laboratories - is another need. Risk analysis and vulnerability of human populations to both scarcity and water quality deterioration is a field of research and management that needs to be improved. Education and capacity building with a systemic and interdisciplinary approach is a need in research and management.

There is a need also to improve our capacity for understanding the impacts of climatic changes on water quality, with research directed to this problem in all continents and regions.

\section{REFERENCES}

Chapman, D. (ed.) (1992) Water quality assessments. UNEP, UNESCO, WHO.

Cisneros, B.J. and Tundisi, J.G. (eds) (2014) Water for the Americas. Inter American Network of Academies of Science.

Cook, C. and Bakker, K. (2010) Water security: debating an emerging paradigm. Global Environmental Change 22, 94-102.

Curmi, E. et al. (2013) An integrated representation of services provided by global water resources. J. Environ. Management 129, 456-462. 
ILEC (2011) Development of ILBM Platform. Process Research Center for Sustainability and Environment, Shiga University. Jorgensen, S.E., Tundisi, J.G. and Matsumura-Tundisi, T. (2012) Handbook of Inland Waters Ecosystem Management. CRC Press.

Rogers, P. (2006) Water governance, water security, water sustainability. In: Rogers P., Lhamas M.R. and Martinez-Cortina, L. (eds). Waters Crisis: Myth or Reality? Taylor \& Francis, London. 331 pp.

Shiklomanov, I.A. (1993) World water resources. In: Gleick, P.H. (ed). Water in Crisis: A Guide to the World's Freshwater Resources. Pacific Institute for Studies in Development, Environment and Security. Stockholm Environmental Institute.

Shiklomanov, I.A. (1999) World water resources and water use, present assessment and outlook for 2050. State Hydrological Institute, St. Petersburg, Russia.

Tundisi, J.G. and Matsumura-Tundisi, T. (2010) Impactos potenciais das alterações do Código Florestal nos recursos hidricos. Biota Neotropica 10(4), 67-76.

Tundisi, J.G. and Matsumura-Tundisi, T. (2012) Limnology. Taylor \& Francis, CRC Press. 832 pp.

Zalewski, M. (2014) Ecohydrology, biotechnology, and engineering for cost efficiency in reaching the sustainability of the biosphere. Ecohydrology and Hydrobiology 14, 14-20. 